\title{
Experimental analysis of reinforced concrete columns strengthened with self-compacting concrete and connectors
}

\section{Análise experimental de pilares de concreto armado reforçados com concreto auto-adensável e conectores}
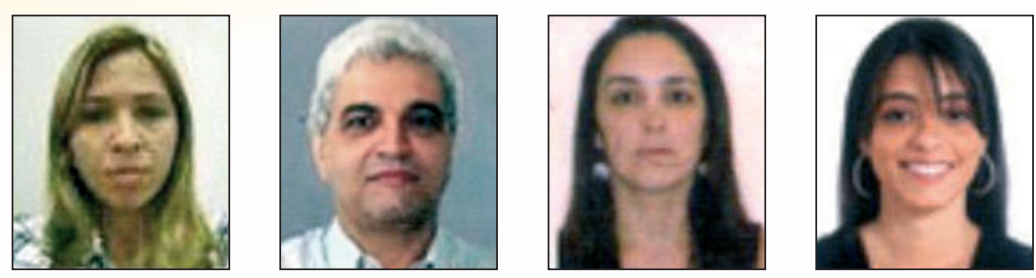

P. P. NASCIMENTO polypaula@hotmail.com

R. B. GOMES b rbggomes@gmail.com

L. L. J. BORGES c lianajardim@ig.com.br

D. L. DAVID d

ddavid@iemebrasil.com.br

\begin{abstract}
There are many problems involving cases of destruction of buildings and other structures. The columns can deteriorate for several reasons such as the evolution and changing habits of the loads. The experimental phase of this work was based on a test involving nine reinforced concrete columns under combined bending and axial compression, at an initial eccentricity of $60 \mathrm{~mm}$.

Two columns were used as reference, one having the original dimensions of the column and the other, monolithic, had been cast along the thickness of the strengthened piece. The remaining columns received a $35 \mathrm{~mm}$ thick layer of self-compacting concrete on their compressed face. For the preparation of the interface between the two materials, this surface was scarified and furrowed and connectors were inserted onto the columns' shear reinforcement in various positions and amounts.As connectors, $5 \mathrm{~mm}$ diameter steel bars were used (the same as for stirrups), bent in the shape of a "C" with $25 \mathrm{~mm}$ coatings.

As a conclusion, not only the quantity, but mainly, the location of the connectors used in the link between substrate and reinforcement is crucial to increase strength and to change failure mode.
\end{abstract}

Keywords: sreinforced concrete, columns, self-compacting concrete, connectors, eccentric load.

\section{Resumo}

Muitos são os problemas envolvendo casos de ruína de edifícios, pontes, entre outros, e especificamente ruína de pilares, que é um dos elos mais importantes do conjunto estrutural. Isto pode ocorrer por falha de projeto, de execução ou ainda, pela evolução e alteração de hábitos. Por isso tem sido de fundamental importância das pesquisas que abordam o comportamento experimental das estruturas. A etapa experimental deste trabalho baseou-se no teste de nove pilares de concreto armado ensaiados à flexo-compressão reta, com excentricidade inicial de $60 \mathrm{~mm}$. Dois pilares foram usados como referência, sendo um com as dimensões originais do pilar e o outro, monolítico, concretado na espessura da peça reforçada. Os demais pilares receberam uma camada de $35 \mathrm{~mm}$ de espessura de concreto auto-adensável na face comprimida. Para preparo da zona de interface entre os dois materiais, procedeu-se com a escarificação e a realização de sulcos ao longo desta superfície, onde foram inseridos conectores ligados a armadura transversal do pilar, variando-se a posição e a quantidade dos mesmos. Pode-se concluir que não só a quantidade, mas principalmente, a localização dos conectores utilizados na ligação entre substrato e reforço, é imprescindível para um aumento de resistência e mudança do modo de ruptura.

Palavras-chave: concreto armado, pilares, concreto auto-adensável, conectores, carga excêntrica.

a Cegef, Federal University of Goiás, polypaula@hotmail.com, Praça Universitária, s/nº - Setor Universitário - CEP 74605-220, Goiânia, Brazil;

b School of Civil Engineering, Federal University of Goiás, rbggomes@gmail.com, Praça Universitária, s/ $n^{\circ}$ - Setor Universitário - CEP 74605-220, Goiânia, Brazil;

Federal Institute of Goiás - IFG, lianajardim@ig.com.br, Av. Pedro Ludovico s/n, Bairro Reny Cury - CEP 75131-500 Anápolis - Goiás

leme Brasil Engenharia Consultiva, ddavid@iemebrasil.com.br, Rua MMDC, 499, São Paulo-SP. 


\section{Introduction}

This study consists of an experimental program included in a research area developed at the School of Civil Engineering of Universidade Federal de Goiás (Federal University of Goiás). Aiming at experimentally comparing the formulation suggested by Mello (2003), Adorno (2004) assayed 12 columns of simple concrete and reinforced concrete subjected to combined bending and axial compression under an initial eccentricity of up to $30 \mathrm{~mm}$. Araújo (2004) complemented this work assaying nine columns with different rates of reinforcement and initial eccentricities of $30 \mathrm{~mm}$ to $60 \mathrm{~mm}$. The experimental and theoretical results with greater concordance occurred in the cases of smaller eccentricities. Omar (2006) studied the behavior of columns strengthened by self-compacting concrete (SCC) on the compressed face and by tension reinforcement on the tensioned face. Nascimento (2006) investigated columns strengthened with SCC on the compressed face and with carbon fiber on the tensioned face. In their works, Omar (2006) and Nascimento (2006) observed load capacity increase on columns under combined bending and axial compression and strengthened with SCC on the compressed face, however, uncoating of the strengthening concrete was also confirmed.

To reduce the effects of premature uncoating of the strengthening concrete and consequently of abrupt column strain, Sahb (2008) suggested improving the link between substrate and strengthening concrete by adding anchor bolts in various amounts and positions. Sahb obtained considerable increase mainly in failure load. Choosing to use anchor bolts and SCC can be considerably positive, nevertheless a greater number of connectors has been shown necessary to obtain a more ductile failure mode.

Based on the findings of previous studies, this work investigates columns submitted to combined bending and axial compression and strengthened with SCC on the compressed face. In addition, the interfacial zone between differently aged concrete is strengthened with open stirrups acting as connectors.

This study's main goal is to check the possibility of strengthening

\section{Figure 1 - Dimensions of original columns ( $\mathrm{mm})$}

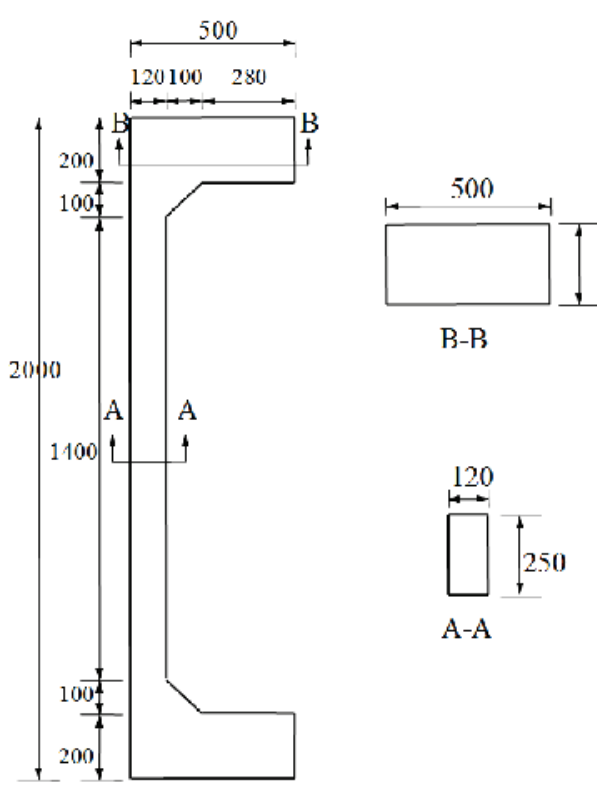

reinforced concrete columns aiming at an increase of ductile failure load to avoid uncoating and enabling a failure by concrete crushing and steel yield. The use of connectors produced with steel bars fixed on the columns' stirrups is a substitute to anchor bolts used by Sahb (2008) and is, to some extent, often used in civil construction.

All strengthened columns had their loads increased when compared to the original reference column $\mathrm{P} 1$. The number and position of connectors influenced loads and failure modes of the models assayed. Both the distance from the center and the spacing

Figure 2 - Cross-section of tested specimens ( $\boldsymbol{e}_{\text {initial }}=$ Initial eccentricity; P= Load; $\mathrm{mm}$ )
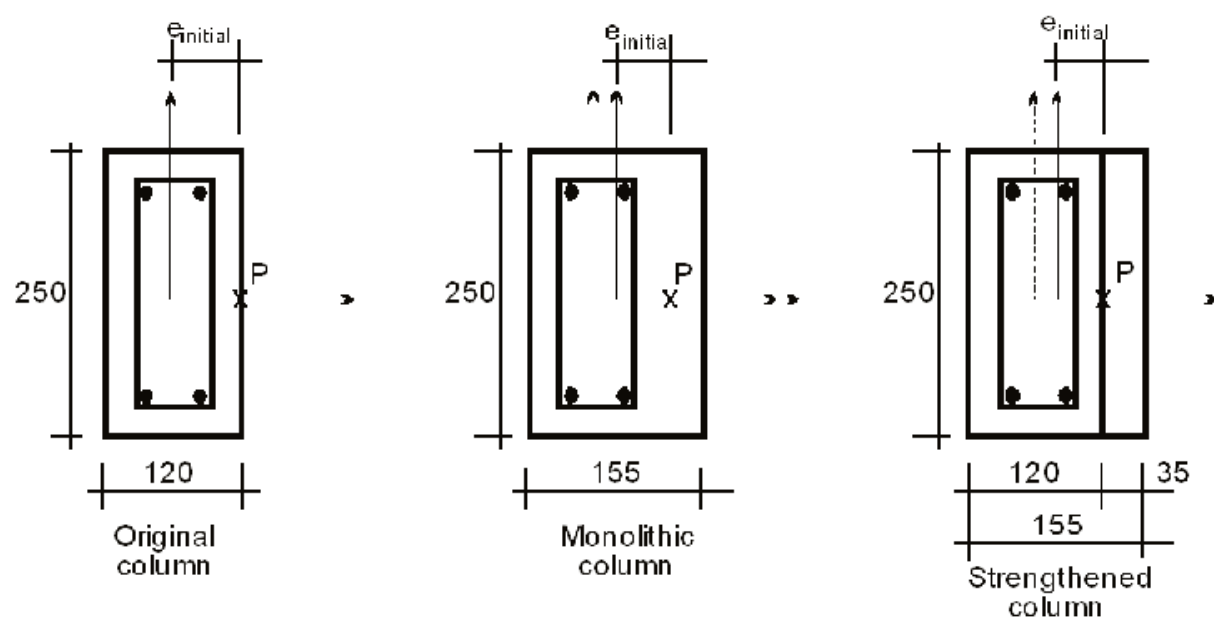
between connectors influence the columns' failure loads and especially their failure modes.

\section{Experimental program}

The experimental program included tests on nine columns whose measurements are shown in Figure 1. These models of tests and the test arrangements are similar to those carried out by Adorno (2004), Araújo (2004), Omar (2006), Nascimento (2006) and Sahb (2008). The columns were cast in two phases. In the first phase, six models were shaped, two of which were used as nonstrengthened reference columns. The remaining columns (second phase) were strengthened with SCC on the compressed face. Their initial eccentricity decreased; therefore, the original load application position was maintained. To ensure bonding between strengthening concrete and substrate, connectors were used in various positions on the interfacial zone of each column, thus improving the model's monolithic behavior and preventing their failure by uncoating of the strengthening concrete.

The P1 model with cross-section of $120 \times 250 \mathrm{~mm}$ represents the original model in conventional concrete. Column P2 is a monolithic reference model; its final section is $155 \times 250 \mathrm{~mm}$, identical to the reinforced column. The remaining columns were strengthened with a $35 \mathrm{~mm}$ thick layer of SCC on the compressed face. Figure 2 shows the characteristics of the transversal sections of the columns assayed. The original longitudinal reinforcement of all columns (Figure 3 ) is composed of four ribbed straight bars with a 10 $\mathrm{mm}$ nominal diameter $\left(A_{s}=314 \mathrm{~mm}^{2}, \rho=1.05 \%\right)$. Figure 4 shows the tension curve $x$ strain of $10 \mathrm{~mm}$ diameter bars. The shear reinforcement is made up of $5 \mathrm{~mm}$ stirrups whose spacing measures $100 \mathrm{~mm}$ in the central area and $50 \mathrm{~mm}$ near the model's edges $\left(\mathrm{f}_{\mathrm{y}}=\right.$ $662 \mathrm{MPa}, \mathrm{e}_{\mathrm{y}}=2.91 \mathrm{~mm} / \mathrm{m}, \mathrm{E}_{\mathrm{s}}=225.3 \mathrm{GPa}$ ). P6A column is identi-

Figure 3 - Detailing of original column reinforcements $(\mathrm{mm})$

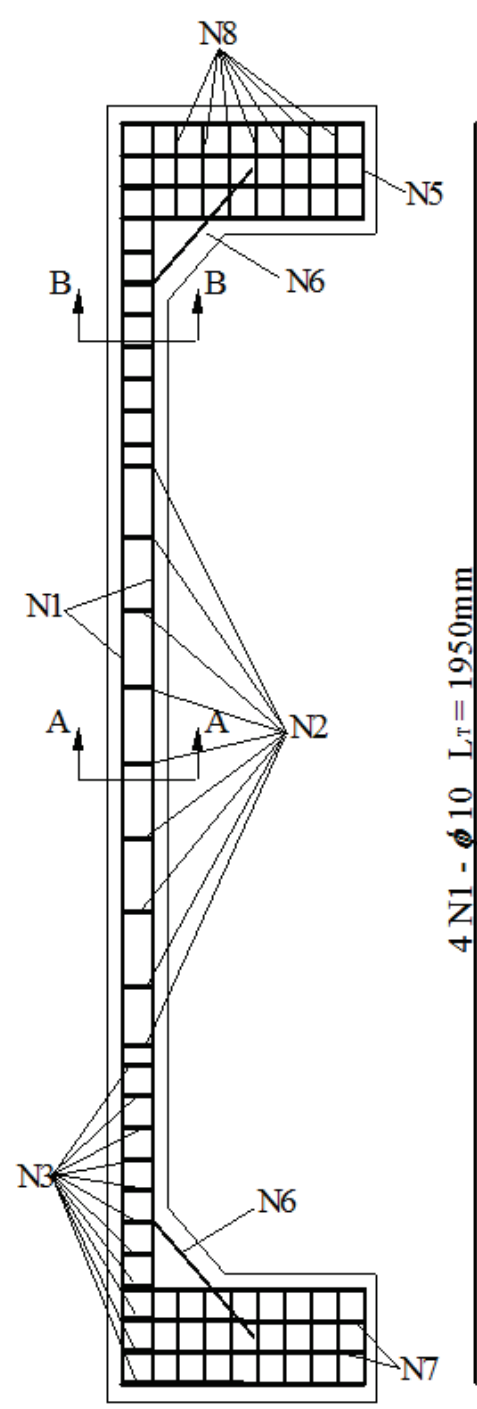

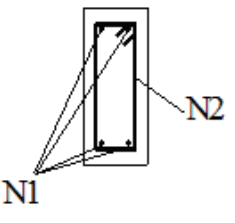

CC

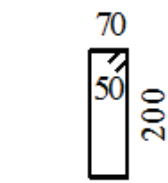

$2 \times 11 \mathrm{~N} 3-\phi 5$ c. 50

$\mathrm{L}_{\mathrm{T}}=640 \mathrm{~mm}$

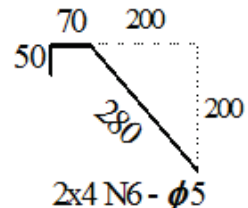

$\mathrm{L}_{\mathrm{T}}=550 \mathrm{~mm}$

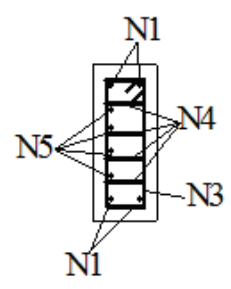

$\mathrm{CC}$

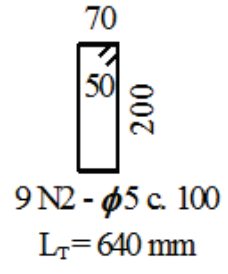<smiles>C1CC2CC1CC1OC2C2CCC1C2</smiles>

$2 \times 11 \mathrm{~N} 4-\phi 5$ c. 50

$\mathrm{L}_{\mathrm{T}}=650 \mathrm{~mm}$
440

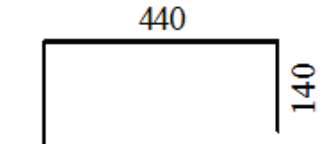

$2 \mathrm{x} 4 \mathrm{~N} 5-\boldsymbol{\phi} 10$

$\mathrm{L}_{\mathrm{T}}=1080 \mathrm{~mm}$

\section{옹}

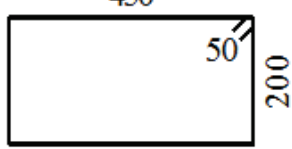

$2 \times 3 \mathrm{~N} 7-\phi 5$

$\mathrm{L}_{\mathrm{T}}=1400 \mathrm{~mm}$

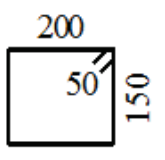

$2 \mathrm{x} 7 \mathrm{~N} 8-\phi 5$

$\mathrm{L}_{\mathrm{T}}=800 \mathrm{~mm}$ 


\section{Figure 4 - Stress-deformations curves of $10 \mathrm{~mm}$ steel bars}

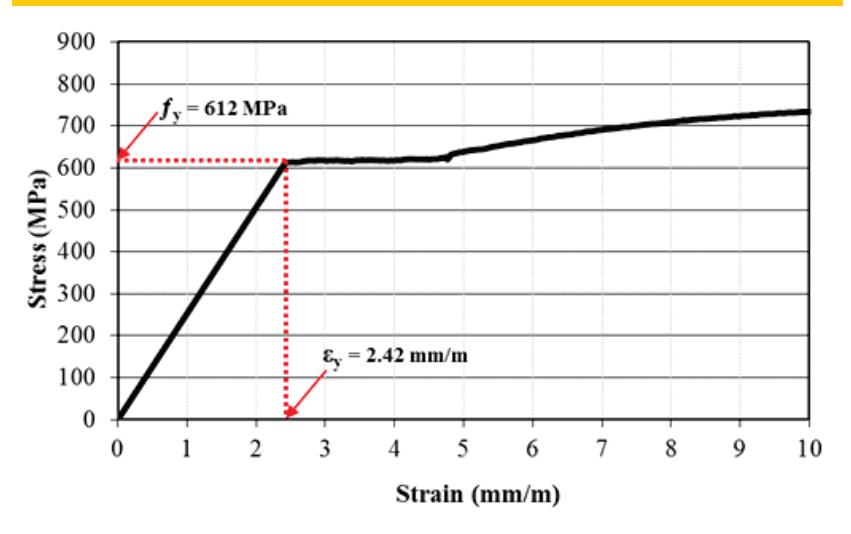

cal to P6 and was made after a power outage had occurred in the laboratory while performing tests on column P6.

Columns were cast horizontally and the tracing was dosed to achieve an average compressive strength value of $30 \mathrm{MPa}$ at 28 days. The conventional concrete used was pumped from the concrete mixer to steel forms and mechanically compacted by an immersion vibrator (25 mm diameter). During casting, 36 cylindrical test samples measuring $150 \mathrm{~mm} \times 300 \mathrm{~mm}$ were molded for concrete characterization. Tests assessed compression strength, tension by diametral compression and elasticity modulus. The columns and the test samples were submitted daily to wet curing and were covered with plastic canvas for seven days. After the seventh day, the columns were removed from the mould and placed in the laboratory until the date of the tests.

Figures 5 and 6 show the increase of the compressive strength of concrete with the age of conventional concrete used in substratum and the SCC used in reinforcement respectively.

The connectors were made from $5 \mathrm{~mm}$ diameter steel bars taken from the same steel batch used for the stirrups of the columns (Figure 5). With a total length of $350 \mathrm{~mm}$, the bars were bent in the

\section{Figure 5 - Compression strength of substrate concrete with age curves}

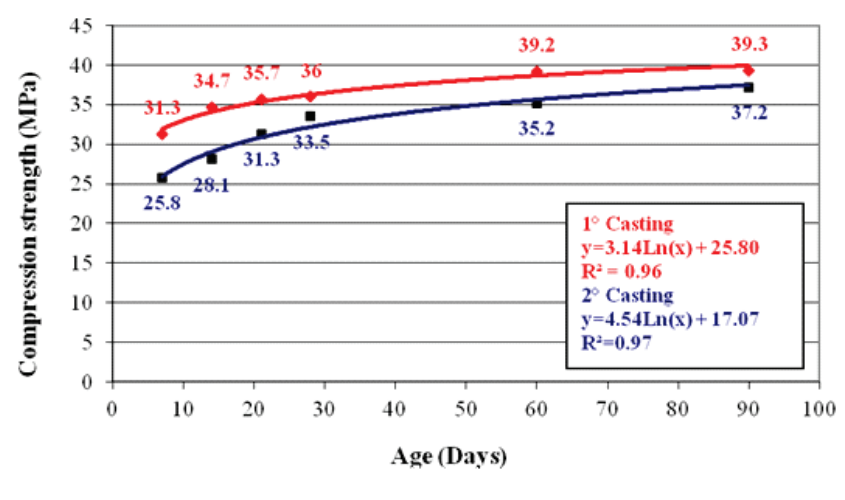

Figure 6 - Concrete compression strength of SCC with age curves

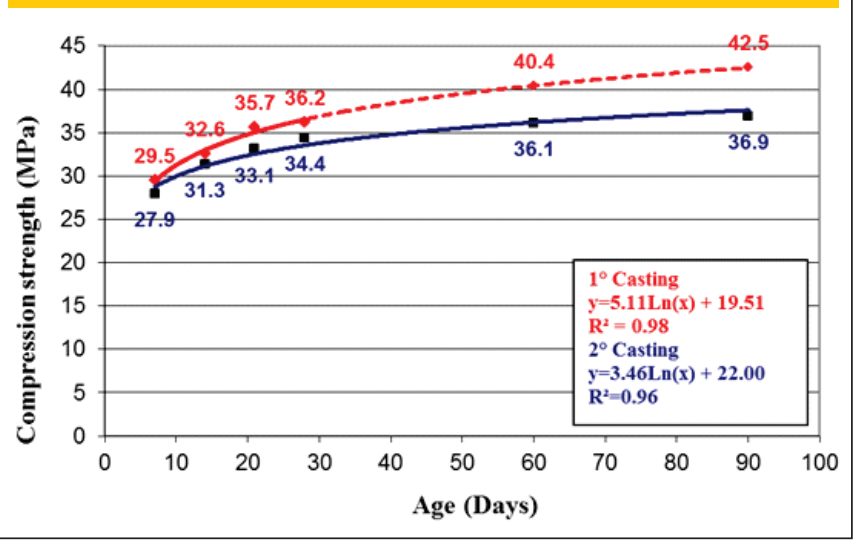

shape of a "c" $140 \mathrm{~mm}$ wide, $35 \mathrm{~mm}$ high and a $70 \mathrm{~mm}$ extension. Once fixed and involving the stirrups of the columns, they allowed a $25 \mathrm{~mm}$ coating.

Figure 7 shows the location of connectors on the compressed face of each column. They are represented by an ongoing line and also show the thickness of the furrows and the distance between them. Furrowing was needed to uncover shear reinforcement, thus enabling the connectors to be tied to the stirrups. The 110 mmwide furrows were accomplished with the use of electrical demolition hammer, manual hammer and metal pointer. With the stirrups in place (Figure 8), the concrete surface was cleaned and the substrate was wet in order to present a saturated dry surface. Structural adhesives were not used for bonding the substrate and the strengthening concrete. Substrate scarification was carried out by spraying only sand all over the compressed face of all the strengthened columns.

To the strengthening the columns, SCC was prepared to achieve an average compression strength of $30 \mathrm{MPa}$ at 28 days. Table 1 shows the proportion of materials used to produce a cubic meter of concrete.

With regard to the slump flow test, the EFNARC (2002) recommends that slump floow values ought to range from 650 to 800 $\mathrm{mm}$. The concrete used to strengthen the columns showed slump flow values of 760 and $750 \mathrm{~mm}$ for the first and second castings, respectively (Figure 9). According to EFNARC (2002), the L-Box test should have a $h_{2} / h_{1}$ relation (height that concrete reaches at the edge of the L-box/height that concrete maintains at the beginning of the L-box) equal to 0.80 . Dosed concrete revealed values ranging from 0.81 to 0.84 (first and second castings, respectively). Gomes et al. (2003) show $\mathrm{Lt}_{20}$ values (reading of the time concrete takes to reach a $20 \mathrm{~cm}$ marking on the L-box) ranging from 0.5 to 1.5 seconds and $\mathrm{Lt}_{40}$ values (reading of the time concrete takes to reach a $40 \mathrm{~cm}$ marking on the L-box) ranging from 2 to 3 seconds. The first casting revealed $L t_{20}=1$ second and $\mathrm{Lt}_{40}=2.5$ seconds, whereas the second casting marked $\mathrm{Lt}_{20}$ $=1$ second and $\mathrm{Lt}_{40}=3$ seconds.

Regarding the V-Funnel 5 min, EFNARC (2002) establishes a limit ranging from 6 to 12 seconds and a difference between the first and the second assays lower or equal to 3 seconds. The first cast- 
Figure 7 - Location of stirrups at compressed face of column
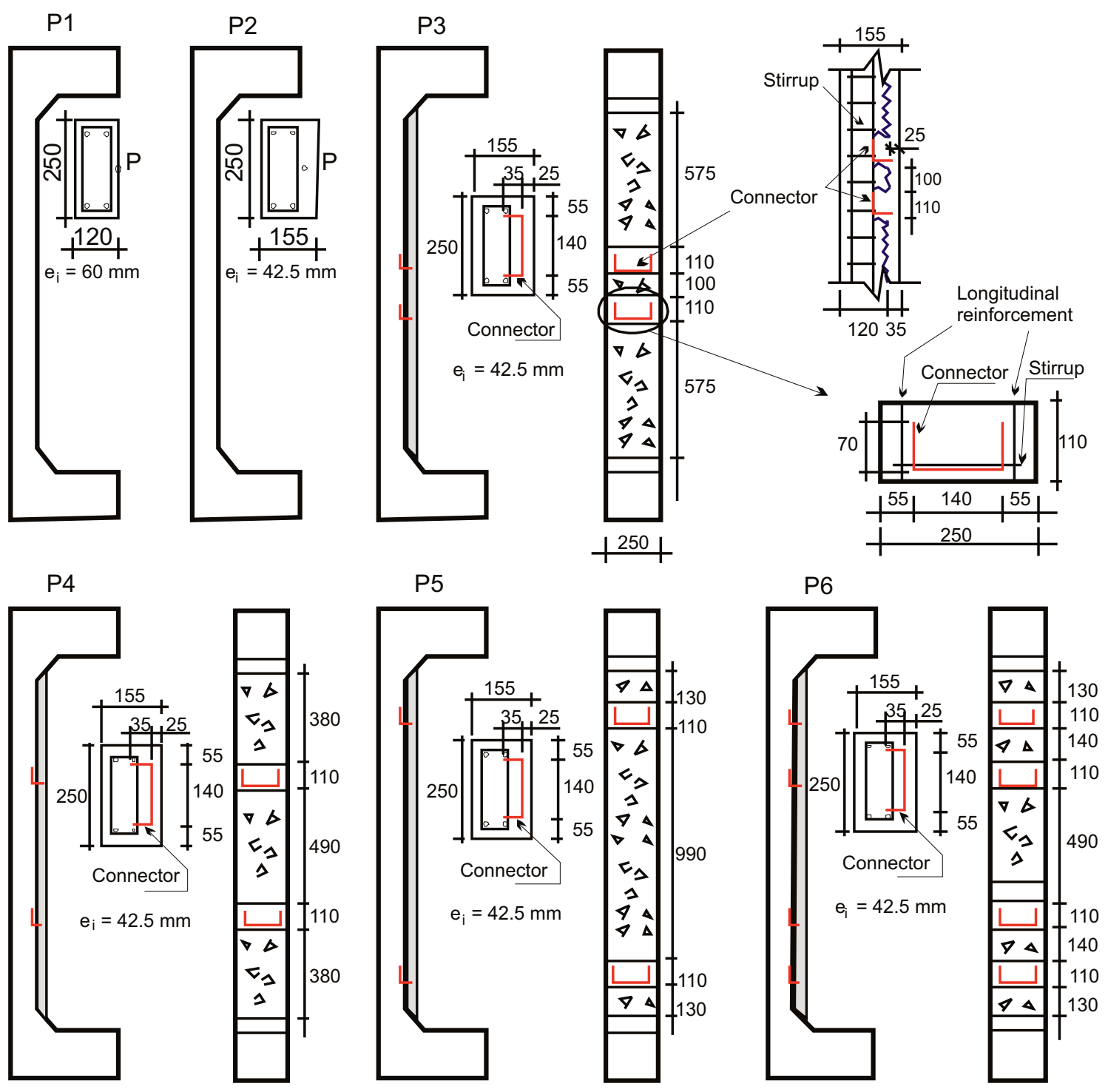

P6A

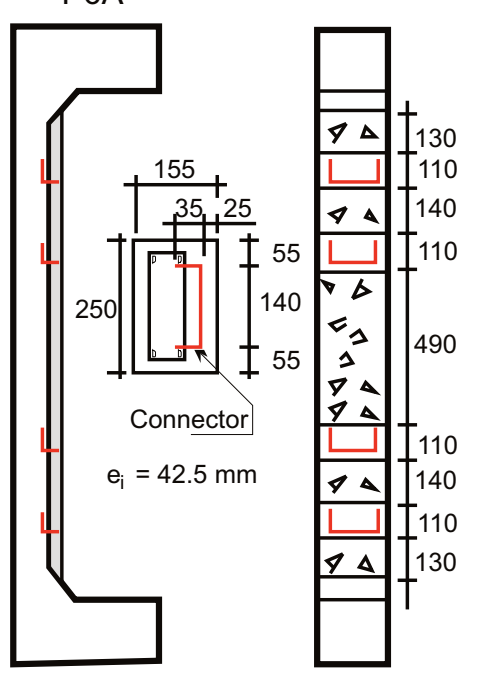

P7

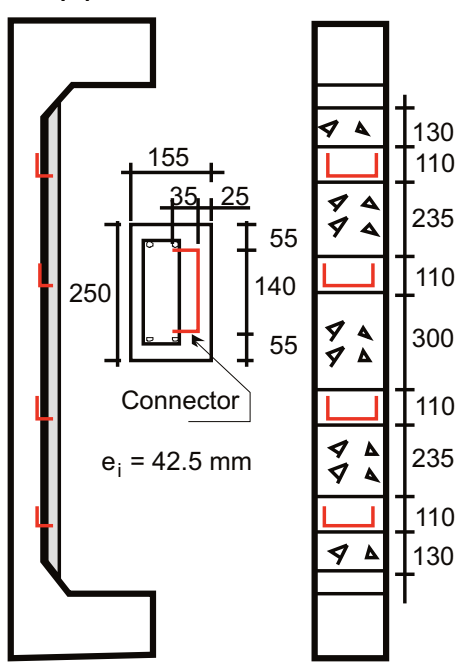

P8

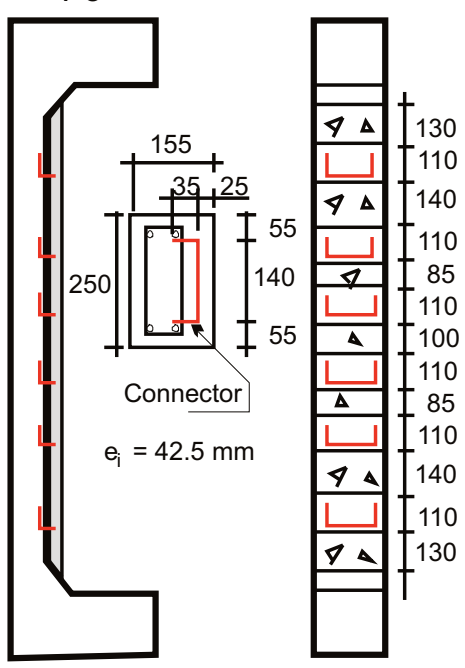


ing revealed 8 and 11 seconds for the first and second tests, respectively, whereas the second casting revealed 7 and 10 seconds for the first and second tests, respectively. The test arrangements consists of a metal porch anchored by tie bars connected to the strong slab. Figure 10 displays the arrangements of the test system used.

\section{Results}

This topic presents and analyses the main results obtained from tests and is divided into three sections: loads and failure modes, horizontal displacements of the columns and finally the strains measured in reinforcements and on the concrete's face.

\section{a) Load and failure mode}

The original reference column P1 failed at $140 \mathrm{kN}$ by steel yielding, whereas monolithic reference column P2 failed at $450 \mathrm{kN}$ by con- crete crushing. The remaining columns failed by concrete uncoating, except column P8, which showed concrete crushing. Strengthened columns P6 and P6A showed greater concrete strain than concrete crushing $(3.5 \mathrm{~mm} / \mathrm{m}-\mathrm{NBR}$ and $3.0 \mathrm{~mm} / \mathrm{m}-\mathrm{ACl})$, but after uncoating. Table 2 shows failure loads, strengths and elasticity moduli of both substrate and strengthening concretes on the assay dates of each model, initial and final eccentricities, maximum steel and concrete strains and failure modes of each column. Strength values of conventional and self-compacting concretes averaged $10 \%$ and $25 \%$, respectively; they were higher for columns P1 to P6 than for columns P6A, P7 and P8. Figure 11 shows the location of the failure in each tested column.

The monolithic column P2 (155 mm x $250 \mathrm{~mm}$ ) failed with a $450 \mathrm{kN}$ load. This column was built to represent the maximum load capacity possible that reinforced columns could reach. The P8 column reinforced with the highest failure load, failed with a load 16\% (Pu $=520 \mathrm{kN}$ ) greater than that of P2. A likely and possible small difference in initial eccentricity could be one reason for the decrease

\section{Figure 8 - Placement of reinforcement connectors}

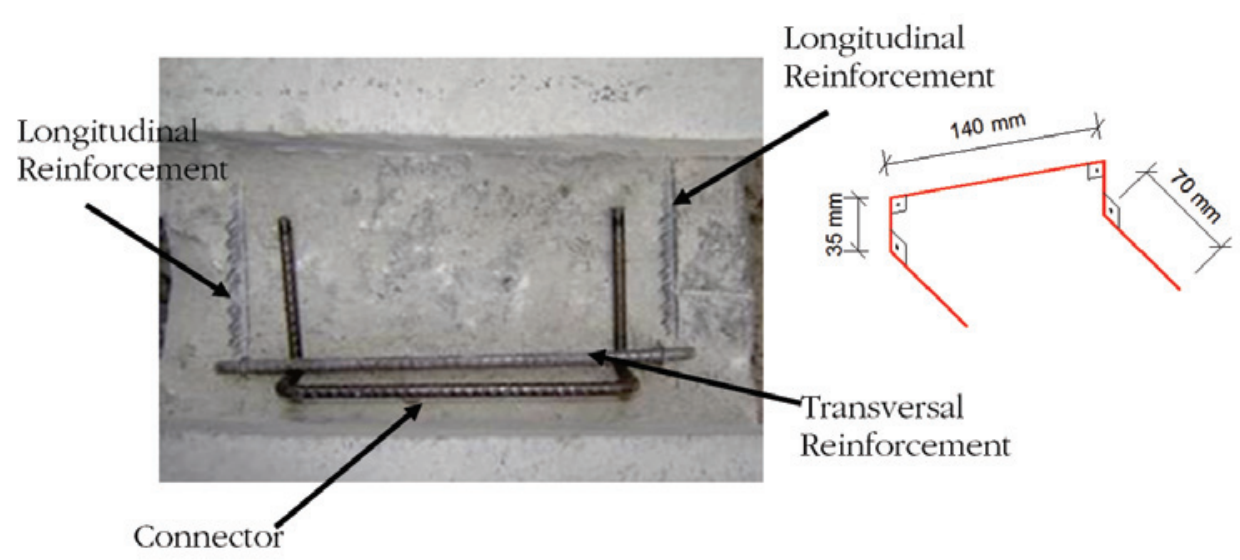

Table 1 - Proportion of substrate materials per $\mathrm{m}^{3}$ of concrete

\begin{tabular}{|c|c|c|}
\hline Materials & $\begin{array}{c}\text { Substrate } \\
\text { Quantity }\left(\mathrm{p} / \mathrm{m}^{3}\right)\end{array}$ & $\begin{array}{c}\text { Strengthening Concrete (SCC) } \\
\text { Quantity }\left(\mathrm{p} / \mathrm{m}^{3}\right)\end{array}$ \\
\hline Cement & $310 \mathrm{~kg}$ & $360 \mathrm{~kg}$ \\
\hline Natural Fine - Coarse Sand & $155 \mathrm{~kg}-233 \mathrm{~kg}$ & 730 kg - 0 kg \\
\hline Artificial Sand & $497 \mathrm{~kg}$ & - \\
\hline Silica & - & $31 \mathrm{~kg}$ \\
\hline Grit $0-1$ & $388 \mathrm{~kg}-619 \mathrm{~kg}$ & $930 \mathrm{~kg}-0 \mathrm{~kg}$ \\
\hline Water & 1551 & 2231 \\
\hline Superplasticizer & - & $3.96 \mathrm{~kg}$ ( $1.1 \%$ on cement) \\
\hline Set Retarder Additive & 2.171 & $2.88 \mathrm{~kg}(0.8 \%$ on cement) \\
\hline- & Slump $(95 \pm 10) \mathrm{mm}$ & Flow test $=700 \mathrm{~mm}$ \\
\hline
\end{tabular}




\section{Figure 9 - Self-compacting concrete (SCC)}

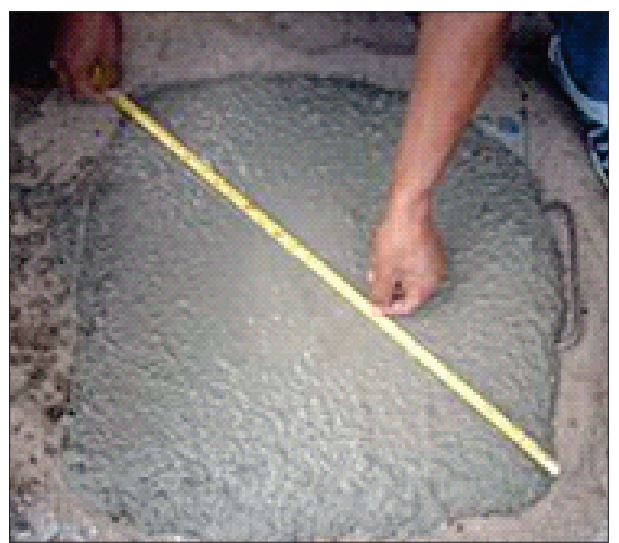

Slump flow test

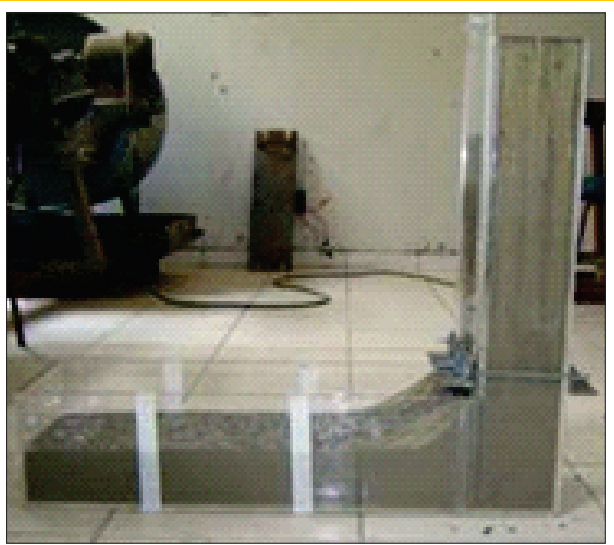

B L-Box test

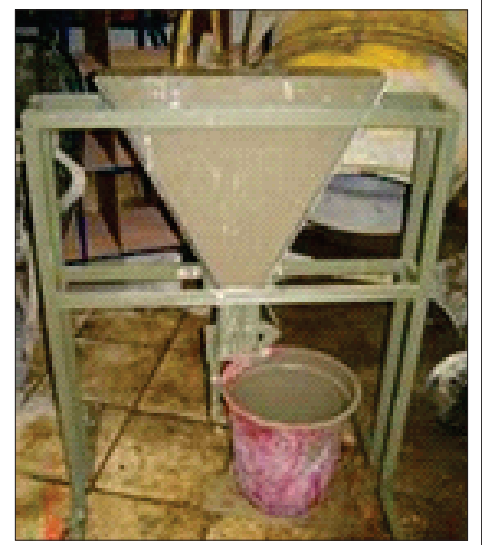

Funnel test of failure load of Column P2. Figure 12 shows the horizontal displacements measured on the tensioned face of all columns (half height) and since the beginning of the tests till values close to failure (to prevent failure, the dial indicators were removed before clear signs of rupture); column P2 showed larger displacements than that of the other columns. This result of column P2 cannot accurately indicate the expected capacity; however, along with columns $\mathrm{P} 5$ and P8, it shows proximity to the limit. Greater control of initial eccentricity is suggested for future tests.

In Table 2 and Figure 11 it is possible to see that not only the number of connectors but also their location influence the failure load of the models tested. It appears that, keeping the number of connectors constant and changing their position may produce considerable load increase, as what happened to the columns P3, P4 and P5. These were strengthened with a single pair of connectors which were progressively moved away from the centre. Column P3 revealed the lowest failure load of the three, whereas column P4 showed a $20 \%$ increase over P3 in failure load and column P5 had a $28 \%$ increase in relation to P3. It appears that the more distant from the center, the greater was the failure load achieved. Despite the load increase, these three columns showed abrupt failure due to uncoating of the strengthening concrete, when compared with the original reference column P1.

Due to the fact that column P5 - strengthened with a pair of connectors placed furthest from the centre of the column, as shown in Figure 7 - was the strongest of the columns reinforced with only one pair of connectors, thus surpassing the load of monolithic reference column $\mathrm{P} 2$ by $11 \%$, and that column P6 had problems during assay by showing low failure load, we decided to cast three more columns. Column P6A had the same characteristics P6 did. As to columns P7 and P8, we decided to place a pair of connectors on the furthest positions from the centre of the column and we also added another pair to P7 and two more pairs to $P 8$.

When comparing columns $\mathrm{P} 6 \mathrm{~A}$ and $\mathrm{P7}$, which were differentiated from each other by the location of the second pair of connectors, we observed that, unlike what we had seen on the columns strengthened with a single pair of connectors, there is an increase in failure load (12\%) 
Table 2 - Failure loads and modes of all columns

\begin{tabular}{|c|c|c|c|c|c|c|c|c|c|c|c|}
\hline Column & $\begin{array}{c}P_{u} \\
(k N)\end{array}$ & $\begin{array}{c}f_{c}^{\text {sub }} \\
(\mathrm{MPa})\end{array}$ & $\begin{array}{c}f_{c}^{\text {st }} \\
(\mathrm{MPa})\end{array}$ & $\begin{array}{c}E_{c}^{\text {sub }} \\
(\mathrm{MPa})\end{array}$ & $\begin{array}{c}E_{c}^{\text {str }} \\
(\mathrm{MPa})\end{array}$ & $\begin{array}{l}\boldsymbol{e}_{\text {inifiol }} \\
(\mathrm{mm})\end{array}$ & $\begin{array}{l}D_{\max } \\
(\mathrm{mm})\end{array}$ & $\begin{array}{c}\Theta_{\text {innal }} \\
(\mathrm{mm})\end{array}$ & $\begin{array}{c}\varepsilon_{s} \max \\
(\mathrm{mm} / \mathrm{m})\end{array}$ & $\begin{array}{c}\varepsilon_{c} \max \\
(\mathrm{mm} / \mathrm{m})\end{array}$ & $\begin{array}{l}\text { Failure } \\
\text { mode }\end{array}$ \\
\hline $\mathrm{Pl}$ & 140 & 42.3 & - & 26.3 & - & 60.0 & 25.3 & 85.6 & -3.3 & 2.7 & EA \\
\hline P2 & 450 & 42.3 & - & 26.3 & - & 42.5 & 17.7 & 60.2 & -2.2 & 4.6 & EC \\
\hline P3 & 390 & 41.9 & 41.1 & 26.1 & 34.5 & 42.5 & 7.8 & 50.3 & -1.7 & 2.9 & DR \\
\hline P4 & 470 & 42.0 & 41.6 & 26.2 & 34.9 & 42.5 & 7.5 & 50.0 & -1.4 & 2.4 & DR \\
\hline P5 & 500 & 42.1 & 42.0 & 26.2 & 35.3 & 42.5 & 7.0 & 49.5 & -0.8 & 2.1 & DR \\
\hline P6 & 370 & 42.2 & 42.3 & 26.3 & 35.5 & 42.5 & 11.6 & 54.1 & -2.0 & 1.7 & DR \\
\hline P6A & 430 & 37.8 & 33.4 & 26.5 & 26.7 & 42.5 & 14.0 & 56.0 & -4.5 & 2.0 & DR \\
\hline P7 & 480 & 38.5 & 35.0 & 26.8 & 28.2 & 42.5 & 9.3 & 51.3 & -4.3 & - & DR \\
\hline P8 & 520 & 38.2 & 34.5 & 26.7 & 27.7 & 42.5 & 4.8 & 47.3 & -2.3 & 3.8 & $\mathrm{EC}$ \\
\hline \multicolumn{12}{|c|}{ 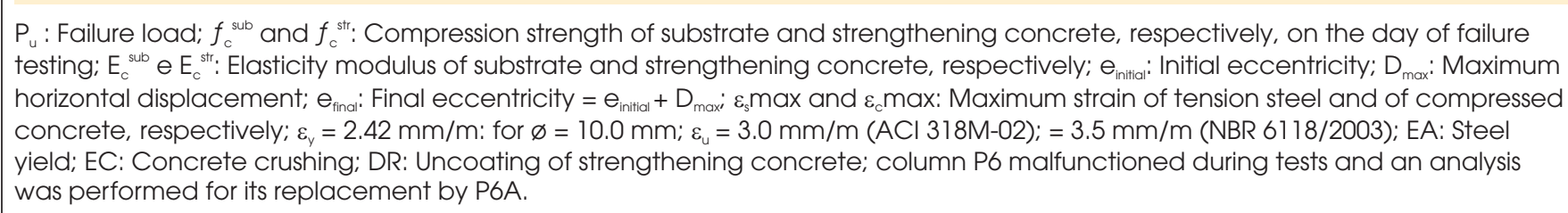 } \\
\hline
\end{tabular}

as the second pair of connectors approaches the centre of the column. However, both columns failed abruptly by uncoating of the strengthening concrete.

Column P8, which had three pairs of connectors, revealed the greatest failure load of all the columns tested. Nevertheless, despite having two more pairs of connectors, the strength increase between P5 and P8 reached only $4 \%$. The highest increase obtained by testing this model was a change in failure mode, from ductile failure to strengthening concrete crushing, similarly to the failure mode shown by monolithic reference column P2, thus meeting the central aim of this work.

\section{b) Displacements}

Figure 12 shows horizontal displacements that took place in the position of the R3 dial indicator for all the columns tested. All strengthened columns showed less inclined curves than reference columns $\mathrm{P} 1$ and P2, suggesting that strengthening results in smaller displacements. The original reference column P1 showed the biggest displacements, whereas strengthened column P8 had the smallest displacements.

Columns P3, P4 and P5 were strengthened with only a pair of connectors, placed in different positions. As shown in Figure 12, the location of the connector may influence the horizontal displacement of the models used; the further the connector stands from the center (P5), the smaller the displacement on the loads near failure. Columns P6A and P7 with two pairs of connectors reveal (Figure 8 ) that the ability to move was increased in relation to the reinforced columns with only one pair of connectors, letting P6A show a final displacement close to the displacement shown by monolithic reference column P2. For this, reinforcement with two pairs of connectors, maintaining the first pair of connectors in the same position used in column P5 and varying the position of the second pair of connectors, reveals that the further away the second pair is from the center, the greater the displacement of the model.

\section{c) Strains}

Figure 13 shows load curves $x$ strain of the reinforcement under the greatest tension of all the columns assayed. With the exception of columns P2 and P5, face reinforcement was under tension on all the remaining columns; this tension was requested since the beginning of the test. For columns $\mathrm{P} 2$ and $\mathrm{P} 5$, the steel only began to be submitted to tension from $280 \mathrm{kN}$ and $400 \mathrm{kN}$ loads onwards, respectively. Of the reference columns, only column $\mathrm{P} 1$ reached steel yield strain value. Column P2's curve shows a tendency to reach yield strength.

Columns P3, P4 and P5, strengthened with a single pair of connectors, failed to reach the reinforcement's yield strain. As it can be observed in Figure 9, the closer to the centre the pair of connectors is, the greater the strains of the reinforcement on the tension column face. Columns P6A and P7, strengthened with two pairs of connectors, showed yielding of the tension face reinforcement. These columns show very similar strain values, but P6A shows the greatest strain. We observed that, by placing the first pair of connectors in the position used in column P5 and then a second pair of connectors in an intermediary position in relation to the first, strain values of the tensed reinforcement increase considerably. Furthermore, in case of using two pairs of connectors, the closer to the centre the second pair of connectors is, the lower the strain value produced by the tensed reinforcement; this is the opposite situation to that of columns with only a single pair of connectors. Column P8, which was strengthened with three pairs of connectors, showed a final steel strain similar to that observed for mono- 
lithic column P2. Similarly to this column, it failed to reach the steel yield strain.

Figure 14 shows load curves $x$ concrete strain on all the columns assayed, with the exception of column P7; two strain gauges on this column located on the compressed face suffered damages. Strains were measured at mid-height on the compressed face of columns. The monolithic reference column P2 reached concrete crushing strain. Despite failing to reach concrete crushing values, column P1 showed a curve which followed this tendency.

Strains measured on the concrete of columns P3, P4 and P5, all strengthened with a single pair of connectors did not reach con- crete crushing strength on the compressed face. In this case, results show that the closer the pair of connectors is to the centre of the column, the greater the strain of the compressed concrete. Column P6A, which was strengthened with two pairs of connectors, also failed to reach concrete crushing strength. Of all the strengthened columns, only P8 showed concrete crushing strain (3.5\%).

\section{Conclusions}

All the strengthened models showed a reduction in horizontal displacements, which were measured at mid-height of the columns'

\section{Figure 11 - Location of column failure on compressed face}

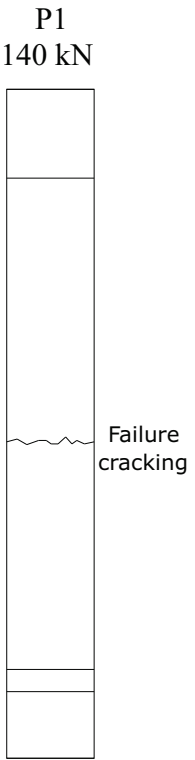

P2 $450 \mathrm{kN}$

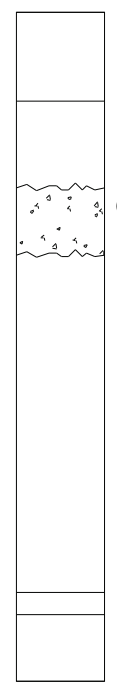

P6

$370 \mathrm{kN}$

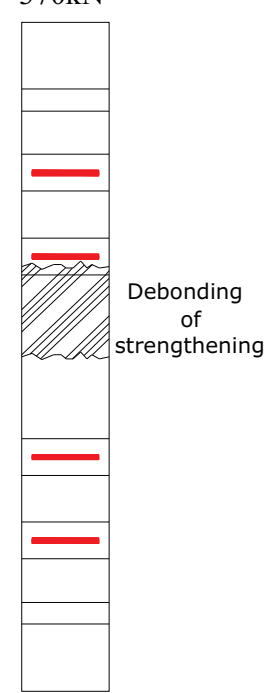

Concrete crushing
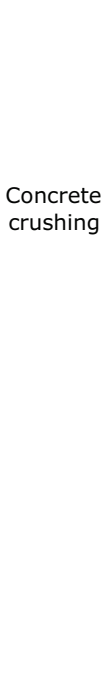

P6A

$430 \mathrm{kN}$

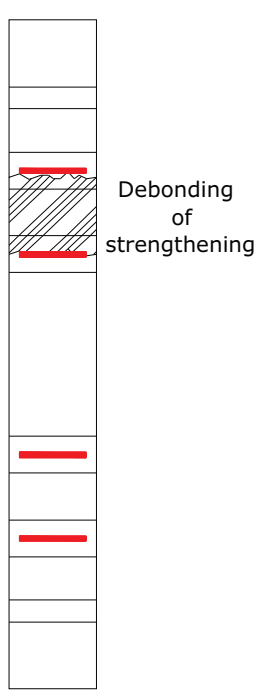

P3 $390 \mathrm{kN}$

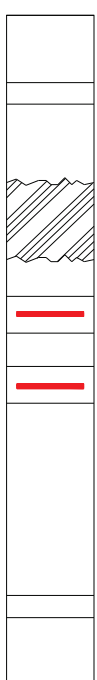

P4

$470 \mathrm{kN}$

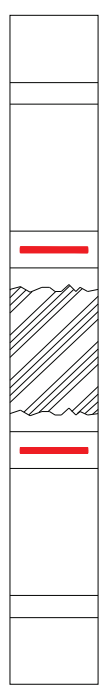

Debonding of strengthening

P7

$480 \mathrm{kN}$

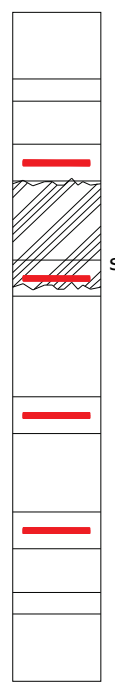

P5 $500 \mathrm{kN}$

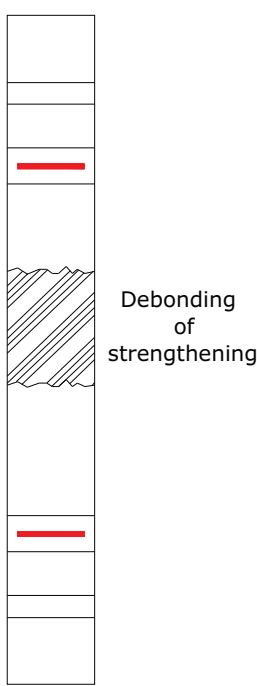

P8 $520 \mathrm{kN}$

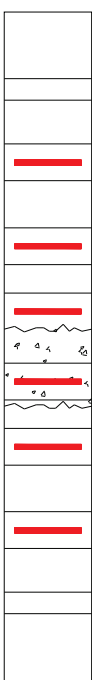

Concrete crushing 


\section{Figure 12 - Load - horizontal displacement curves (R3)}

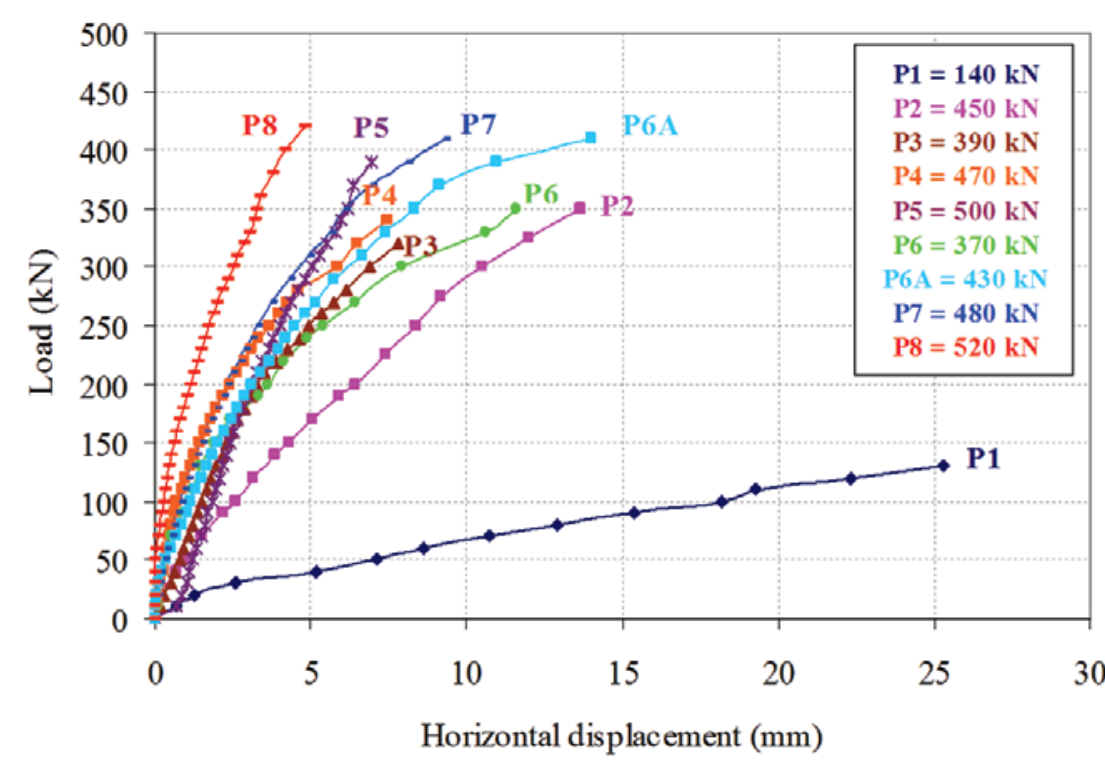

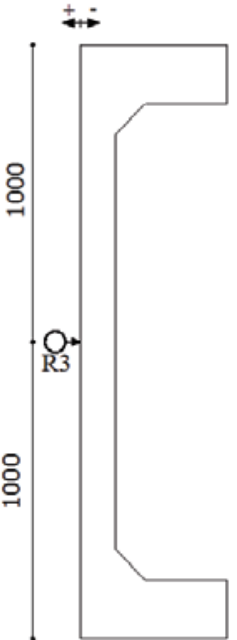

$(\mathrm{mm})$ tension face, in contrast with the reference columns. This means that strengthening on the compressed face with the addition of concrete as well as the use of connectors on the strengthening concrete provided adherence between substrate and strengthening concrete, which are differently aged. This contributed to column stiffening. Column P8 was strengthened with the highest number of connectors: three pairs were placed $105 \mathrm{~mm}, 300 \mathrm{~mm}$ and 550 $\mathrm{m}$ from the column centre. This column showed the smallest horizontal displacements at mid-height among all the models tested. As for the reference columns, the original column $\mathrm{P} 1$ reached strain of steel yield and although the monolithic column P2 had not reached

Figure 13 - Load - steel strain curves

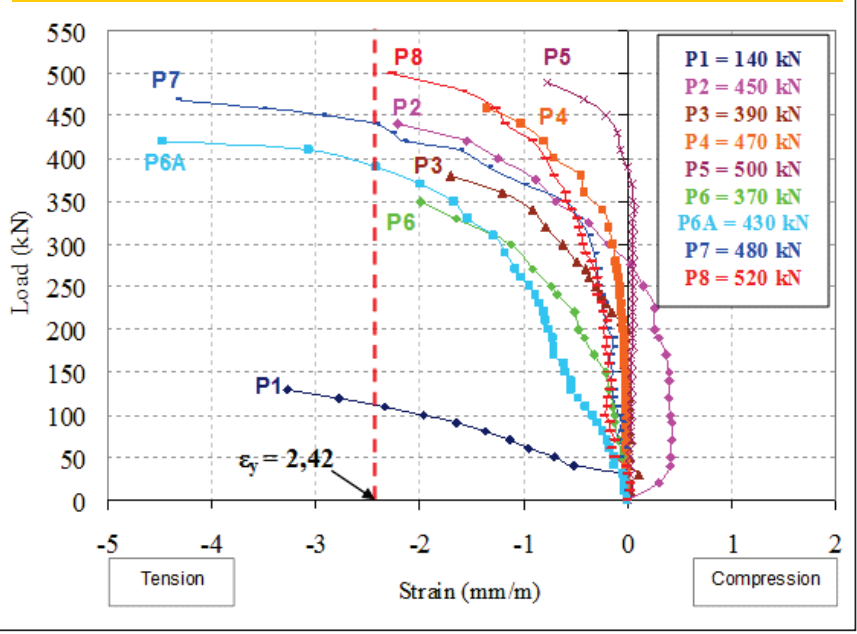

the yield limit, it presented a curve tending to such occurrence. The columns reinforced with only one pair of connectors (P3, P4 and P5) did not reach strain of steel yield, therefore, the closer to the center the connectors were, the largest were the values of strain in the reinforcement under tension. The columns reinforced with two pairs of connectors (P6A and P7) reached strain of steel yield. Column P8, reinforced with three pairs of connectors showed final strain on the steel similar to that shown on monolithic column P2, and in the same way, had not reached strain of steel yield.

The monolithic reference column P2 presented crushing strain of the compressed concrete. Column P1 presented a curve tending

Figure 14 - Load $x$ concrete strain curves

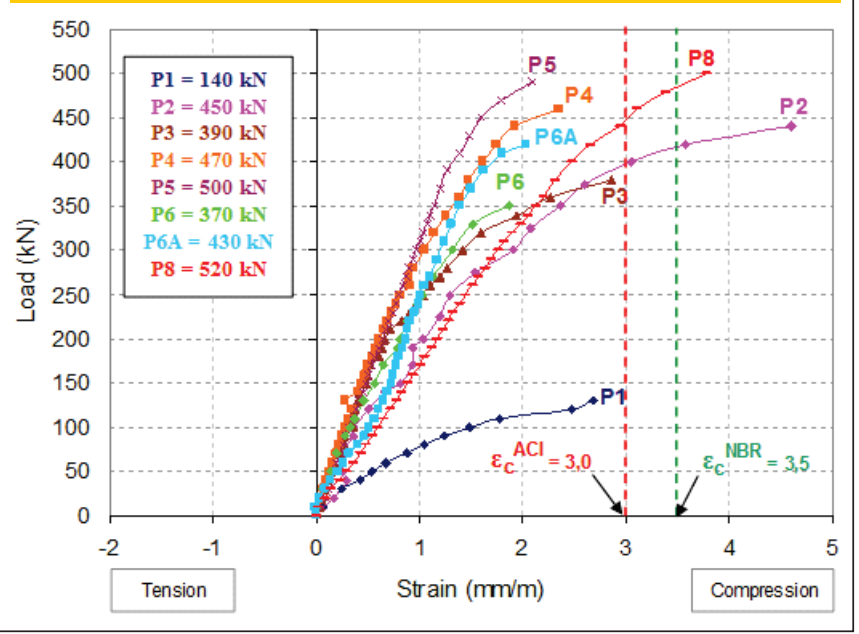


to concrete crushing. Of all strengthened columns, only P8, with three pairs of connectors, showed crushing strain.

All strengthened columns had their failure loads increased when compared to original reference column P1. The number and position of connectors influenced loads and the failure mode of the models assayed. Columns with a single pair of connectors presented higher failure loads than those columns whose pair of connectors was placed further from the centre. Column P3, whose connectors were closer to the centre $(105 \mathrm{~mm})$, failed at $390 \mathrm{kN}$, whereas $\mathrm{P} 4$, whose connectors were placed $300 \mathrm{~mm}$ from the centre, failed at $470 \mathrm{kN}$. Column P5 had its pair of connectors placed $550 \mathrm{~mm}$ from the centre, and its failure load occurred at $500 \mathrm{kN}$.

Columns P6A $\left(P_{u}=430 \mathrm{kN}\right)$ and P7 $\left(P_{u}=480 \mathrm{kN}\right)$, strengthened with two pairs of connectors, had their outer pair of connectors placed 550 $\mathrm{mm}$ from the centre. The inner pair was located $300 \mathrm{~mm}$ from the centre in column P6A and $205 \mathrm{~mm}$ in column P7. These columns showed that, unlike columns strengthened with only one pair, there is an increase in failure load as the inner pair of connectors approaches the centre of the column (P7). The failure mode of these models also occurred abruptly due to uncoating of the strengthening concrete.

Column P8, whose three pairs of connectors were placed $105 \mathrm{~mm}$, $300 \mathrm{~mm}$ and $550 \mathrm{~mm}$ away from the centre, revealed the greatest failure load of all the columns tested. The failure load of column P8 was 1.15 times higher than that of column P2.

The results showed that the use of this type of connectors can be a viable option, providing a significant increase in failure load, in strains and in horizontal displacements. Spacing between connectors, positions and numbers of inappropriate connectors may, despite the possibility of increase in failure load, lead to sudden failures with displacement of the compressed section.

\section{Acknowledgements}

The authors gratefully acknowledge to CNPq and Procad/Capes for their financial support. They also thanks to Carlos Campos Consultoria Limitada, Impercia and Realmix for providing materials and for performing material characterization tests.

\section{References}

[01] MELLO, E. L. Reinforced concrete: Limited resistance to flexure under combined bending and axial compression loads. University of Brasilia Ed., FINATEC, Brasília, 2003. 224 p.

[02] ADORNO, A. L. C. Theoretical and experimental analysis of concrete columns and reinforced concrete columns under eccentric load. D.Sc. thesis, Department of Civil and Environmental Engineering, University of Brasilia, Brasilia, DF, Brazil, 399p, 2004. (In Portuguese).

[03] ARAÚJO, L. M. B. Theoretical and experimental analysis of reinforced concrete columns subjected to axial load and flexure. M.Sc. thesis, Federal University of Goias, Goiânia, Brazil. 196p, 2004. (In Portuguese).

[04] NASCIMENTO, P. P. Reinforced concrete columns strengthened with carbon fibers and self-compacting concrete (CAA). 2006. 97f. UEG, Anápolis, Goiás, 2006.
[05] OMAR, M. Y. M. Experimental analysis of reinforced concrete columns strengthened with self-compacting concrete (CAA). M.Sc. thesis, Federal University of Goias, Goiânia, Brazil. 266p, 2006. (In Portuguese).

[06] SAHB, K. F. P. Experimental analysis of reinforced concrete columns under eccentric load strengthened with self-compacting concrete (CAA) and anchor bolts. M.Sc. thesis, Federal University of Goias, Goiânia, Brazil. 224p, 2008. (In Portuguese).

[07] EUROPEAN FEDERATION FOR SPECIALIST CONSTRUCTION CHEMICALS AND CONCRETE SYSTEMS (EFNARC). Specification and guidelines for self-compacting concrete. In: EFNARC. February, 2002.

[08] GOMES, P. C. C. Optimization and Characterization of High-Strength Self-Compacting Concrete. 2002. 139f. D.Sc. Thesis, Universitat Politècnica de Catalunya, Barcelona, 2002.

[09] BRAZILIAN ASSOCIATION STANDARDS. NBR 6118:2003 - "Design of concrete structures". Rio de Janeiro, 2004, (in Portuguese).

[10] ACI COMMITTEE 318. Buiding Code Requirements for Reinforced Concrete and Commentary - ACl 318/02. Detroit, American Concrete Institute, 2001. 